\title{
The interaction between freezing tolerance and phenology in temperate deciduous trees
}

\section{Yann Vitasse*, Armando Lenz and Christian Körner}

Institute of Botany, University of Basel, Basel, Switzerland

\section{Edited by:}

Michael Wisniewski, United States Department of Agriculture -

Agricultural Research Service, USA

\section{Reviewed by:}

Rajeev Arora, lowa State University, USA

Lawrence V. Gusta, University of Saskatchewan, Canada

${ }^{*}$ Correspondence:

Yann Vitasse, Institute of Botany, University of Basel,

Schoenbeinstrasse 6, CH-4056 Basel, Switzerland

e-mail: vitasse.yann@gmail.com

\begin{abstract}
Temperate climates are defined by distinct temperature seasonality with large and often unpredictable weather during any of the four seasons. To thrive in such climates, trees have to withstand a cold winter and the stochastic occurrence of freeze events during any time of the year. The physiological mechanisms trees adopt to escape, avoid, and tolerate freezing temperatures include a cold acclimation in autumn, a dormancy period during winter (leafless in deciduous trees), and the maintenance of a certain freezing tolerance during dehardening in early spring. The change from one phase to the next is mediated by complex interactions between temperature and photoperiod. This review aims at providing an overview of the interplay between phenology of leaves and species-specific freezing resistance. First, we address the long-term evolutionary responses that enabled temperate trees to tolerate certain low temperature extremes. We provide evidence that short term acclimation of freezing resistance plays a crucial role both in dormant and active buds, including re-acclimation to cold conditions following warm spells. This ability declines to almost zero during leaf emergence. Second, we show that the risk that native temperate trees encounter freeze injuries is low and is confined to spring and underline that this risk might be altered by climate warming depending on species-specific phenological responses to environmental cues.
\end{abstract}

Keywords: biogeographical limits, cold acclimation, freezing resistance, fundamental niche, leaf-out, phenology, plant-climate interactions, temperate trees

\section{INTRODUCTION}

Since approximately 11,000 years, temperate trees have evolved into an interglacial period, the Holocene, which is warmer than the preceding 100,000 years, i.e., the last glacial period. While the Holocene is climatically stable when viewed from a geological time perspective, the climate of temperate areas is highly variable from the perspective of a trees' lifespan, yet with a predictable seasonality. As a result, temperate trees have evolved to cope with the seasonal occurrence of freezing temperature. One part of the adaptation to seasonality is cold acclimation in autumn and a dormancy period in winter, followed by a deacclimation period in spring. The initiation and the progress of the acclimation and deacclimation periods and the onset of growth are mediated by temperature and photoperiod (Polgar and Primack, 2011). A good match between these physiological processes and climatic conditions is essential for the persistence of trees in temperate areas.

The term phenology is commonly used to refer to the timing of the seasonal development in plants, most commonly, the visible changes in plant appearance such as greening in spring, flowering, and senescence. In deciduous trees growing in temperate climates, the timing of phenological events affects annual growth, reproductive success, and competitive abilities of trees (Myneni et al., 1997; Hasenauer et al., 1999; Chuine and Beaubien, 2001; Chuine, 2010). Thus, phenology has a major impact on fitness and distribution of tree species. Currently, global warming is modifying the phenology of temperate trees, particularly the onset of spring, in Europe (e.g., Menzel, 2000; Menzel et al., 2006; Fu et al., 2014b; Kolárová et al., 2014), North America (e.g., Beaubien and Freeland, 2000; Schwartz and Reiter, 2000) and Eurasia (e.g., Chen et al., 2005; Ma and Zhou, 2012). Changes in phenology may even feed back on climate (Richardson et al., 2013). Since about two decades, there is a renewed interest in the overall impact of phenological shifts in forest ecosystems due to climate change. It has recently led to substantial advances and new perspectives in the understanding of the environmental factors driving tree phenology (e.g., Körner and Basler, 2010; Basler and Körner, 2012; Fu et al., 2013; Dantec et al., 2014; Laube et al., 2014; Polgar et al., 2014). Concurrent with the shift in phenology, the risk of trees to encounter freezing damages is changing, yet it is still unclear whether the risk increases or not (Hänninen, 1991; Taulavuori et al., 2004; Augspurger, 2009; Bennie et al., 2010; Hänninen and Tanino, 2011).

Here we aim at providing an overview of the interplay between phenology, species-specific freezing resistance and low temperature range limits of temperate trees. Instead of sequentially reviewing the annual phenological cycle of temperate trees, we emphasize the interaction between tree phenology and seasonal climate in an evolutionary context. Thus, we will highlight the role of seasonal variations in climate as the main evolutionary pressure that has led deciduous trees to develop long-term adaptations and rapid responses to escape or tolerate freezing temperatures in temperate areas. We will first focus on the winter dormancy period, which can be considered as a long-term evolutionary response of temperate trees to tolerate extreme low temperatures. We further will summarize knowledge on genetic adaptation of phenology 
and cold hardiness developed by tree populations living at the cold edge of their distribution range. Next, we will show the ability of trees to rapidly modify their cold hardiness and phenology in response to climatic fluctuations. In particular, we discuss to what extent dormant and active buds are able to rapidly acclimate to colder temperature. Finally we will discuss which period of the year is the most critical in terms of the risk to encounter freezing damages and how this risk could change with climate warming.

\section{SEASONALITY IN TEMPERATE CLIMATE SEASONAL CHANGES OF TEMPERATURE AND PHOTOPERIOD}

Temperate climate generally refers to climatic conditions that prevail at latitudes between 40 and $60^{\circ}$. Temperate zones are characterized by large temperature oscillations at daily, monthly, and annual scale and a seasonal variation of photoperiod that increases with increasing latitude. While the photoperiodic signal is stable for any day of the year, temperature fluctuations are unpredictable. Within each of the four seasons large drops in temperature can occur from 1 day or 1 week to the next, yet within a seasonally distinct range. Furthermore, the contrast in temperature among the seasons increases with increasing continentality (distance from the coast). Trees in temperate regions must cope with freezing temperatures during any time of the year, especially from late autumn to early spring and in some exceptional years during early autumn or late spring. The freeze-free period is reduced toward northern latitudes and higher elevations as well as with the degree of continentality. For instance, Fagus sylvatica L., one of the most dominant tree species in Europe, experiences on average 320 freeze-free days near the south western edge of its distribution in France, less than 290 freeze-free days near its upper latitudinal distribution in Denmark or close to its eastern range limit in Romania, and about 166 freezefree days at its upper elevational limit in the Alps (Figure 1, means calculated over the whole 20th century). However, this does not mean that the risk of freezing injuries for temperate trees increases with increasing latitude or elevation (Lenz et al., 2013), because the onset of the growing season shifts in parallel (see next section). In contrast to temperature, day length follows the same seasonal variation in a given location from year to year and thus, constitutes a reliable marker of the progression of the seasons.

\section{SHORT TERM TEMPERATURE FLUCTUATIONS WITHIN SEASONS}

In temperate areas, it is relatively frequent that a cooler or a warmer mass of air causes abrupt changes in temperature within a $24 \mathrm{~h}$ period. While warm spells associated to severe drought can be highly critical for temperate trees in summer, they can also lead to a certain degree of dehardening in winter or early spring, which can be damaging in combination with a subsequent freeze

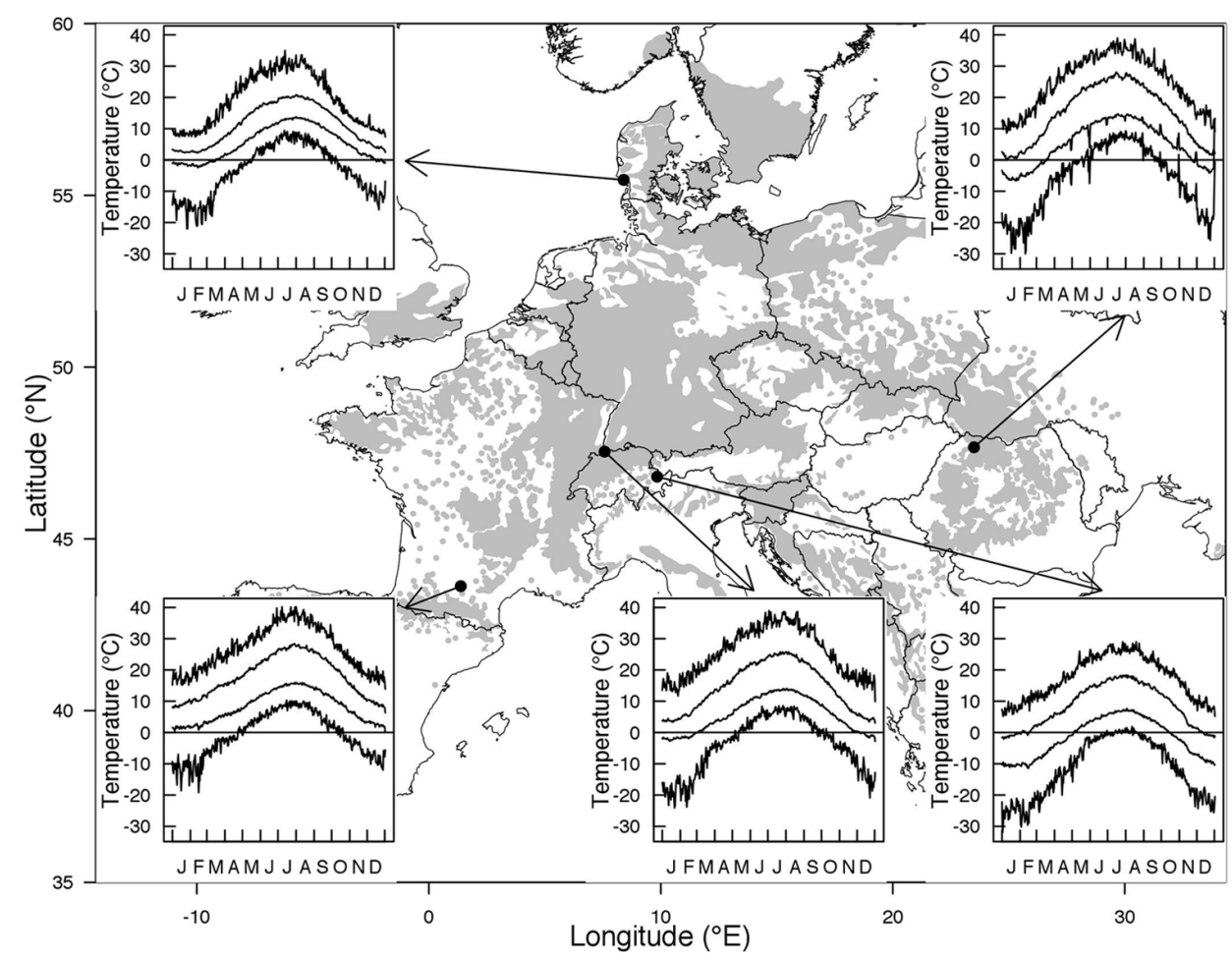

FIGURE 1 | Distribution range of Fagus sylvatica along with climatic characteristics at the northern and southern edge of the distribution and at low versus high elevation in central Europe. Absolute maximum, mean maximum, mean minimum, and absolute minimum temperature for a given day of the year in the period 1901-2000 are shown. The selected stations were Toulouse (France, $43.6^{\circ} \mathrm{N} 1.4^{\circ} \mathrm{E}, 151 \mathrm{~m}$ a.s.I) in the West, Nordby (Denmark, $55.5^{\circ} \mathrm{N} 8.4^{\circ} \mathrm{E}, 4 \mathrm{~m}$ a.s.l) in the North, Baia Mare (Romania, $47.7^{\circ} \mathrm{N}$, $23.5^{\circ} \mathrm{E}, 216 \mathrm{~m}$ a.s.I) in the East, Binningen (Switzerland, $47.5^{\circ} \mathrm{N} \mathrm{7.6}{ }^{\circ} \mathrm{E}, 316 \mathrm{~m}$ a.s.l) at low elevation, and Davos (Switzerland, $46.8^{\circ} \mathrm{N} 9.8^{\circ} \mathrm{E}, 1594 \mathrm{~m}$ a.s.l) at high elevation. 
event. Cold spells are potentially damaging in autumn and spring if the tissues are not hardy enough. Cold fronts move fast and can produce sharp decreases of temperature by rapidly replacing the warm (lighter) air. Cold spells can last from hours to days and are known to have caused food shortage and famines in the past centuries by killing crops before the harvest. In the northern hemisphere, the polar jet stream flowing west to east results from the difference between cold temperatures in the Arctic and warmer temperatures in the mid-latitudes and is strongly influencing the weather in the northern hemisphere at temperate latitudes. Recent studies suggest that the movement of the polar jet stream is changing with global warming because the northern polar regions warm much faster than the rest of the world (Semenov, 2012; Screen and Simmonds, 2013), which is amplified by a recent dramatic loss of artic ice and snow cover (Screen and Simmonds, 2010). Hence, the temperature difference between Arctic and mid latitudes shrinks and causes larger wavelength of the polar jet stream and weakens its flowing velocity (Francis et al., 2009). This has dramatic implications for climate stochasticity because the more the jet stream undulates north and south, the more changeable and extreme the weather is (Screen and Simmonds, 2013). Current Artic warming is therefore enhancing the frequency and magnitude of weather extremes in mid latitudes (Semenov, 2012).

\section{SPATIAL AND YEAR-TO-YEAR IN VARIABILITY IN TEMPERATURE AND LEAF-OUT DATES}

Tree taxa in temperate regions experience a large variability in temperature during the year, across years but also across the distribution area of a species, as shown in Figures $\mathbf{1}$ and $\mathbf{2}$ for Fagus sylvatica, one of the most dominant tree species in Europe. Interestingly, the variation in daily minimum temperature experienced by European beech is smaller among sites at the different limits of the distribution range than the inter-annual variation in temperature observed at a given location (Figure 2). The large variability in temperature experienced by a single tree in temperate areas among different years explains the annual fluctuations in the timing of leaf-out, flowering, and fruit ripening of temperate trees. For instance, an analysis in four tree species observed in the International Phenological Gardens established in Europe since the 1950s, Chmielewski and Rötzer (2002) reported variability in the beginning of the growing season of up to 25 days across Europe over the examined period of 30 years (1969-1998). A remarkable example is the analysis of the well-known Marsham phenological records from Norfolk, England (Sparks and Carey, 1995). This long-term series of phenological observations, gathering more than 150 years of observations, revealed a range of approximately 2 months ( $\sim 40-70$ days) in the timing of leaf-out dates of major European tree species such as Quercus robur, Fagus sylvatica, Acer pseudoplatanus, Fraxinus excelsior, Sorbus aucuparia, Tilia spp., Carpinus betulus, or Betula pendula (Figure 3). The analysis of this unique long-term series shows that the occurrence of leaf-out dates follows a Gaussian distribution indicating that early springs occurred as frequent as late springs over this period (Figure 3). Fagus sylvatica is known as one of the most sensitive tree species to photoperiod in its spring phenology in Europe (Vitasse and Basler, 2013).
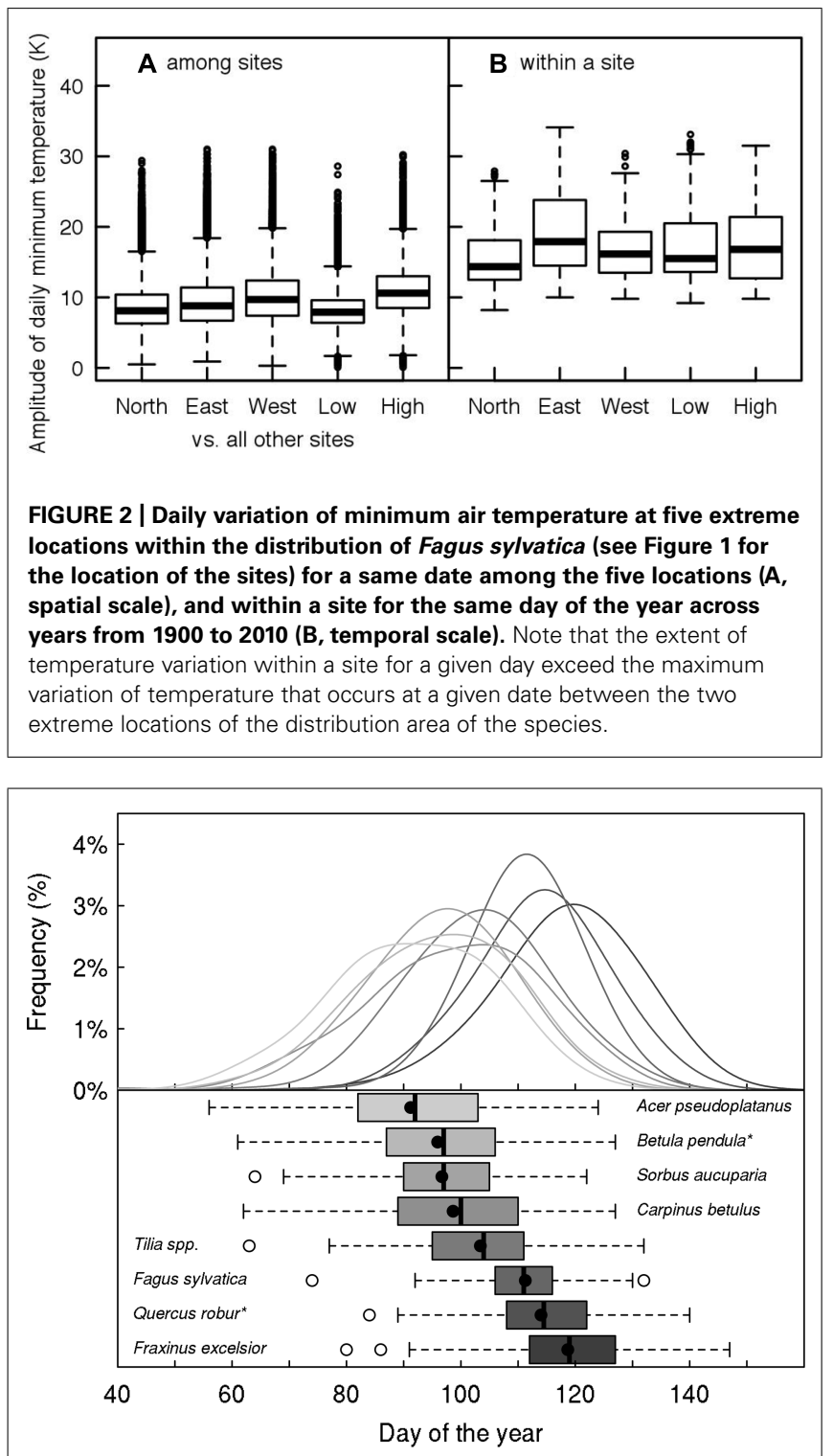

FIGURE 3 | Marsham phenological records (Sparks and Carey, 1995). The upper panel shows the frequency of distribution of the leaf-out dates in Norfolk (UK) for eight temperate tree species over the period 1736-1958 (between 158 and 178 years available, depending on species). The distribution was fitted by a Gaussian-Kernel density distribution with a bandwidth of 7 days for each species. The box-plots show median, quartiles, and extremes of the phenological data, with the mean given as filled circle. Species names followed by an asterisk indicate that this is the probable species but we are uncertain.

Noteworthy, it is also the species that exhibited the lowest variation in its leaf-out timing in the Marsham phenological records (Figure 3).

When variability in flushing date is discussed, it is crucial to separate spatial (e.g., high vs. low elevation) from temporal (year to year) variation, and variation within a genotype vs. different genotypes. Further it is key to separate tree species that belong to different life history strategies (early successional, short lived, r-strategists vs. late successional, long-lived, k-strategists), trees 
that grow in the wild versus trees planted in cities or aboreta (provenances of unknown origin), and wild trees in situ vs. cultivated trees or exotic trees. Further, seedling or sapling responses must be separated from adult tree responses since they are known to operate under different phenology control than adults (Vitasse, 2013). Finally it makes a large difference if oceanic locations with mild winters and hardly any significant frost regimes are compared with continental climates. Variability in phenology across such vastly different plant types and life conditions do not permit generalization (theory development). The variability that matters is that within a given adult genotype at a given location and we lack such long-term phenological series.

\section{LONG-TERM EVOLUTIONARY RESPONSES OF TREES TO SEASONALITY}

In the northern hemisphere, the seasonal climate of temperate regions has led winter deciduous trees to adapt by a dormancy period in winter, with no active growth, a low metabolic activity and a high tolerance against freezing temperature. In the following sections we will focus on the dormancy period and the environmental cues that trigger and release trees from this physiological stage. Then, we will discuss the structural and physiological adjustments during the dormancy period required to achieve a high degree of freezing tolerance. Finally, we will discuss the longterm genetic adaptation in cold hardiness among different tree populations inhabiting contrasting climatic conditions.

\section{ENVIRONMENTAL CUES INVOLVED IN THE REGULATION OF DORMANCY, ACCLIMATION AND DEACCLIMATION}

The regulation and the maintenance of bud dormancy are highly complex as it involves the interaction of internal and external factors. For instance, it is assumed that the dormancy of most temperate tree species is released after they have passed through a certain duration of chilling temperatures between 0 and $5^{\circ} \mathrm{C}$ (Coville, 1920) which interact to variable degree depending on species with an increasing photoperiod (Cannell and Smith, 1986; Heide, 1993; Caffarra and Donnelly, 2011; Vitasse and Basler, 2013; Basler and Körner, 2014; Laube et al., 2014; Polgar et al., 2014). Chilling requirement and photoperiod controls allow temperate trees to avoid a too early development (in the case of warm winter weather) in relation to the probability of freezing. Longer durations of chilling and longer photoperiod decrease the thermal time required for budburst, i.e., decrease the warmth requirement for budburst (Sarvas, 1972; Basler and Körner, 2014; Dantec et al., 2014; Laube et al., 2014). This non-linear relationship between photoperiod and temperature may reflect the non-linear increase in spring temperatures along with the decrease in probability of freezing temperatures (Cannell, 1997) and can be seen as the most prominent adaptation to escape frost injuries to developing leaves by the appropriate timing for flushing (Lenz et al., 2013).

Dormancy induction is considered as a prerequisite to cold acclimation during the hardening period (Weiser, 1970; Pagter and Arora, 2013). It is widely recognized that the shortening of the photoperiod in combination with lower temperatures in autumn initiate and strengthen cold acclimation (e.g., Till, 1956; Weiser, 1970; Flint, 1972; Christersson, 1978; Arora et al., 2003; Beck et al., 2004; Kalberer et al., 2006).
Decreasing photoperiod and temperature cause active tissues to gradually enter into a dormant state (Welling et al., 2002), called hereafter endodormancy (Lang et al., 1987). During this process overwintering tissues harden to reach a maximum cold hardiness in mid-winter, and cells are then in a physiological state that allows them to withstand very cold temperatures. Under actual winter conditions, deciduous broad-leaved trees generally exhibit freezing resistance ranging from -15 to $-25^{\circ} \mathrm{C}$ in roots, from -25 to $<-35^{\circ} \mathrm{C}$ in shoot buds and from -30 to $-50^{\circ} \mathrm{C}$ in twigs and stems (Till, 1956; Flint, 1972; Larcher, 2005; Körner, 2012). Nordic Betula species and other cold adapted species were found to tolerate temperature lower than $-70^{\circ} \mathrm{C}$ in full dormancy (Sakai and Larcher, 1987; Körner, 2012). After an artificial hardening, freezing resistance of trees in winter can be further enhanced. For instance, twigs of Salix pentandra L. or Morus alba L. were shown to tolerate the temperature of liquid nitrogen $\left(-196^{\circ} \mathrm{C}\right)$ when artificially hardened (Sakai, 1960; Stushnoff and Junttila, 1986).

In late winter and early spring, woody temperate species undergo two forms of deacclimation (Kalberer et al., 2006). "Active deacclimation" refers to a loss of cold hardiness as part of a general enhancement of metabolism and development in response to the combined effect of past chilling experience, photoperiod, and concurrent temperatures. Active deacclimation by temperature (forcing) typically comes into play during the spring-ecodormancy stage, once chilling and photoperiod requirements are fulfilled. In contrast, "passive deacclimation" of freezing tolerance results from the exposure of fully acclimated (hardy) trees in mid winter to small or moderate increases of temperature. Long days were shown to enhance deacclimation-associated growth and reduce reacclimation ability at specific developmental stages in Pinus sylvestris (Leinonen et al., 1997). Recently, Basler and Körner (2014) showed that the onset and duration of bud growth are co-controlled by photoperiod and temperature in cuttings of Fagus sylvatica and Picea abies and to a lower extent in Quercus petraea. However, photoperiod presumably plays a role in deacclimation-associated growth only for tree species that are photoperiodic sensitive in their spring development (Species experimentally found to be photoperiodic sensitive species in spring listed in Way and Montgomery, 2014).

\section{ESCAPE, AVOIDANCE, AND TOLERANCE OF FREEZING TEMPERATURES}

To cope with freezing temperatures, temperate tree species adopt three strategies: escape, avoidance, and tolerance (Levitt, 1972; Körner, 2012). First, temperate deciduous trees escape the effect of freezing temperature on leaves in winter, by shedding them in autumn (the stress is not present for these tissues). To escape freezing damage to young sensitive leaves in spring, trees can adjust the timing of budburst. Escape of freezing temperatures by adjusting spring phenology constitutes a prominent adaptation of trees in temperate regions. Thus, as previously mentioned, the timing of budburst reflects the combined effects of three main environmental cues (chilling, photoperiod, and warm temperatures) in a way that young leaves are rarely exposed to severe freeze events. Yet, the relative contribution of each cue and their interactions remain to be clearly deciphered (Basler and Körner, 2014; Laube et al., 2014). 
Avoidance can be regarded as the minimization or the exclusion of the stress effect on a given tissue. Trees can avoid ice formation in xylem parenchyma cells and bud tissue by the socalled supercooling process, where water remains in the liquid phase at sub-zero temperature, even though more stable phases would exist (Supercooling process in plants reviewed by Wisniewski et al., 2014). The limit for homogenous ice nucleation of water, i.e., in the absence of any nucleating agents, is supposed to be around $-39^{\circ} \mathrm{C}$. Supercooling of water can occur in buds and xylem parenchyma cells anywhere from a few degrees below zero down to as much as $-60^{\circ} \mathrm{C}$ (Wisniewski and Fuller, 1999; Körner, 2012). For supercooling to be possible, the presence of ice barriers is necessary to prevent the spread of ice into tissues with water in a supercooled state. Tannins - related to phenols - and flavonol glycosides have been reported to act as anti-nucleating agents inside xylem parenchyma cells, promoting deep supercooling (Kasuga et al., 2010; Kuwabara et al., 2013). The exact role of antifreeze proteins in promoting deep supercooling is still unclear. Freezing avoidance by deep supercooling has been evidenced mostly in xylem parenchyma cells, bud meristems and flower buds of woody species in winter, but little is known about its possible role in freezing avoidance in leaf buds of temperate trees during the ecodormancy phase (Wisniewski et al., 2014). The formation of ice barriers itself could be regarded as a further mechanism to avoid freezing damage since ice barriers constitute physical barriers against propagation of ice in plant tissue (Kuprian et al., 2014; Wisniewski et al., 2014). A further avoidance strategy for a given tissue is extra organ freezing, which can be observed to protect leaf primordia in many tree species (Sakai, 1982; Pearce, 2001).

The tolerance of extracellular ice formation (intracellular ice formation would inevitably lead to cell death) is achieved via physiological changes, many of which enhance the tolerance of cells to dehydration. Indeed, extracellular ice formation induces a dehydration of the cell. The water potential of ice is much lower than the one of liquid water. During extracellular ice formation, an osmotic gradient is established between the intracellular water and the extracellular ice. Consequently, water is diffusing or transported out of the cell to balance the osmotic gradient, and cells dehydrate. Lethal freezing is usually related to damages to cell membranes when the freeze-induced dehydration exceeds the dehydration tolerance of the cell (Steponkus, 1984). The first stage of cold acclimation is induced by shorter day length in autumn and causes the accumulation of starch and lipid reserves in the overwintering tissues. Then, the second stage is regulated by cold subzero temperatures which induce numerous physiological and ultrastructural changes in the cells. Among the most important changes are the synthesis of stress proteins and dehydrins, changes to membranes, including the reduction in membrane located carriers and changes in phospholipid composition, ultrastructural changes of the cell, increasing concentrations of proline and gamma aminobutyric acid (GABA), as well as the synthesis of polyamines, and changes in carbohydrate concentrations. Most of these molecular ultrastructural changes have been discovered and documented during the second half of the last century in herbaceous plants. For a more detailed review of physiological alterations during hardening, we refer to Weiser (1970), Sakai and Larcher (1987), Kalberer et al. (2006), Preston and Sandve (2013), and Wisniewski et al. (2014).

\section{GENETIC ADAPTATIONS}

As long-lived organisms with a large distribution range, trees must cope with very contrasting climates. Many tree species exhibit long distance pollen and moderate seed dispersal abilities (Kremer et al., 2012; Gerber et al., 2014). It is thus not surprising that temperate trees exhibit a high phenological plasticity. (Kramer, 1995; Vitasse etal., 2010, 2013), in spite of clear genetic differentiations related to the climate of origin (Vitasse et al., 2009a; Alberto et al., 2013). As previously demonstrated, the temporal variation of temperature in a single site exceeds the variation of temperature among extreme locations of the distribution area of a given tree species (see Figure 2). Therefore the high phenological variation in response to temperature enables temperate trees to adjust their growth period to a large range of climatic conditions within the distribution range rather than to be locally adapted. For instance, by adjusting the timing of leaf-out to temperature and photoperiod along elevational gradients, trees avoid the risky period in terms of freezing temperature for sensitive tissues such as new leaves (Lenz et al., 2013), irrespective of their elevation of origin, though high-elevation provenances seem slightly less flexible (Vitasse et al., 2013). Nevertheless along climatic gradients, a convergence of genetic differentiation among populations has been documented for deciduous temperate trees both for the timing of bud set and bud burst and cold hardiness. Thus, when planted in common gardens, seedling populations of winter deciduous temperate species from high latitude or elevation - i.e., colder climate - generally exhibit later spring phenology (Engler, 1913; Burger, 1926; Langlet, 1971; Barnett and Farmer, 1980; Vitasse et al., 2009a, 2013; Alberto et al., 2011; Körner, 2012) and earlier budset in summer (reviewed in Alberto et al., 2013) than populations from warmer climate, following the natural in situ variation, i.e., showing a co-gradient variation. European beech is an exception as the opposite pattern for the timing of budburst has been documented in numerous studies, suggesting that for this species a short season restricts the fitness more than the risk of freeze damage does (Vitasse et al., 2013; Lenz et al., 2014).

The genetic and phenotypic clines in cold hardiness also exhibit a co-gradient variation: young tree populations from high latitude were found to be more resistant than southern populations in winter when planted in common gardens as well as when assessed directly in situ (Larsen, 1986; Li et al., 2002, 2003; Viveros-Viveros et al., 2009; Kreyling et al., 2012b; Kreyling et al., 2014). The genetic cline is more marked along latitudinal gradients, because photoperiod controls the growth cessation and subsequently the initiation of the cold acclimation period in most temperate tree species (Junttila and Kaurin, 1990). The magnitude and the speed of deacclimation may differ between ecotypes as a result of genetic and environmental interactions. For instance, northern ecotypes of Betula pubescens were found to deacclimate slower than those from more southern latitudes (Taulavuori et al., 2004). While a few studies reported genetic differentiation among populations grown in common gardens in winter (Li et al., 2003; Kreyling et al., 2014), to our knowledge, no study has yet investigated 
whether there is a genetic differentiation among population in their freezing resistance during the most sensitive phenological stage, i.e., during flushing. Additionally to genetic differentiation in phenology and freezing resistance, slower growth rate in populations of young trees originating from colder climates has been generally reported in a number of studies both for conifers (Engler, 1913; Langlet, 1971; Rehfeldt, 1994; Oleksyn et al., 1998; Saenz-Romero et al., 2006; Rweyongeza et al., 2007) and broadleaved tree species (Engler, 1913; Langlet, 1971; Premoli et al., 2007; Vitasse et al., 2009a, 2014b), whereas only weak genetic differentiation was found in leaf morphological traits among populations along elevational gradients (Bresson et al., 2011; Vitasse et al., 2014b). These findings could reflect a trade-off between growth rate and freezing resistance. Regarding competition for light or water availability, rapid gain in height seems advantageous in warmer climate, whereas populations growing in colder climates, that are usually more open, have evolved under natural selection for greater general robustness, including cold hardiness (Loehle, 1998; Körner, 2012). However the trade-off between growth allocation and physiological adaptations to cold conditions is currently challenged. Indeed, the lower biomass increment found in populations originating from colder environment when planted in common gardens could result from the fact that these populations ceased to grow at shorter photoperiod, as elegantly shown recently in Salix species (Savage and CavenderBares, 2013) and early on in Cornus stolonifera (Smithberg and Weiser, 1968).

Remarkably, temperate trees are able to rapidly adjust their cold hardiness to temperature fluctuations during the endodormancy phase and to a lower extent during the acclimation and deacclimation phases via molecular and cellular adjustments. This is the focus of the next section

\section{RAPID RESPONSES TO TEMPERATURE FLUCTUATIONS}

In temperate climates, rapid reductions in temperature - within a few hours - are possible during almost any time of the year. To cope with such short term changes in temperature, temperate trees employ first, a generally high level of freezing resistance during any time of the year, when compared with long-term records of low temperature extremes for a given period of the year (Lenz et al., 2013), and second, they developed the ability to rapidly acclimate the degree of freezing tolerance.

\section{RAPID ACCLIMATION AND DEACCLIMATION}

During endodormancy temperate trees exhibit their maximum freezing resistance. For shoot buds, it has been reported to range between -25 and $<-35^{\circ} \mathrm{C}$ (Larcher, 2005). However this range reflects what is measured at a time $t$. Several studies have demonstrated that these values can substantially fluctuate if temperatures prior to the measurement are exceptionally cold or warm (Pisek and Schiessl, 1947; Sakai, 1966; Sakai and Larcher, 1987; Neuner et al., 1999). Similarly, artificial hardening or sub-zero acclimation reveals the potential of trees to increase the cold hardiness of their overwintering tissues. Using herbaceous plants as model, this rapid acclimation to subzero temperatures seem to involve numerous unknown and stress-related genes (Herman et al., 2006) but the genetic and molecular basis of rapid acclimation during sub-zero temperatures seem distinct from that of cold acclimation during the hardening period (Le et al., 2008). Pronounced acclimation (as well as deacclimation) of freezing resistance by $5-15^{\circ} \mathrm{C}^{\circ}$ in response to slight sub-zero temperatures have been observed in two conifer species and two dwarf shrub species (Pisek and Schiessl, 1947). In the light of these observations it appears very unlikely that native temperate trees suffer from freezing injuries in winter and that their low temperature range limits are set by absolute minimum temperature in winter. Consistently, longterm absolute minimum temperatures at species' low temperature range limits, recorded over more than eight decades, were found to be much warmer than the maximum freezing tolerance of any temperate tree species (Lenz et al., 2013; Kollas et al., 2014).

Deacclimation in late winter and early spring proceeds much faster than acclimation in autumn (Kalberer et al., 2006), which makes trees vulnerable when a warm spell is followed by an abrupt cold spell, especially in late winter and spring. For instance, 1 day of deacclimation (warm greenhouse) in winter reduced the freezing resistance of Pyrus malus by about $15^{\circ} \mathrm{C}$, whereas three cold days are necessary to recover the hardiness (Howell and Weiser, 1970). The authors also pointed out that the reacclimation after a deacclimation can only partially recover the initial degree of cold hardiness and this discrepancy increases with the progress of spring. Thus, in contrast to winter, during and prior to flushing, tissues reacclimate poorly in response to cold temperature (Pisek and Schiessl, 1947; Kalberer et al., 2006). The closer to bud break, the less easily buds become rehardened. Once warm temperatures have initiated growth resumption in spring, deacclimation is no longer reversible, as was demonstrated in Picea abies (Leinonen et al., 1997). This is why late spring freezing events are highly critical and play a key role in defining the low temperature range limit of temperate trees (Lenz et al., 2013; Kollas et al., 2014).

No correlation was found among species or ecotypes between the rate of deacclimation and the maximum cold hardiness reached before the deacclimation took place, nor with the climate of origin (Kalberer et al., 2006). The rate of deacclimation might relate more to the degree of temperature fluctuations to which trees are exposed rather than to low temperature per se. In other words, evolutionary pressure might have diminished the deacclimation potential during dormancy for species or populations that evolved in locations with frequent rapid fluctuations of temperatures in winter, while species or populations inhabiting more stable climates may be more sensitive to deacclimation in response to warm winter temperatures (Ogren, 2001). This is a field to be further explored given it is not known what fluctuation it needs for deacclimation to occur (Kalberer et al., 2006). Temperature fluctuations may also affect the timing of leaf-out as recently suggested by Kalvāns etal. (2014) and Wang et al. (2014).

Thus, the actual freezing resistance of a given tissue depends on the general hardening stage, plus the degree of short-term hardening in response to the recent history of temperatures. While the potential for acclimation is large in autumn and winter, it dramatically decreases over the course of spring. In contrast, the potential for deacclimation is low in late autumn and winter and exponentially increases in spring. 


\section{RECOVERING FROM XYLEM EMBOLISM IN WINTER}

Another consequence of the winter season in temperate areas is the winter embolism of the xylem that occurs in most temperate angiosperms. The embolism of xylem in winter is induced by freeze-thaw cycles (Sperry and Sullivan, 1992). When water freezes, the dissolved air gasses, causing air bubbles in conduits as the ice thaws (the "thaw-expansion hypothesis," as for instance demonstrated in Pinus contorta by Mayr and Sperry, 2010). However, there is no evidence of lasting conduit failure, hydraulic continuity is seemingly re-established. At the least, the formation of new vessels in spring restores hydraulic conductivity, which is crucial in ring porous taxa which produce new vessels before bud burst (e.g., in Quercus sp., Cochard and Tyree, 1990), while others (diffuse porous) do so after bud burst (e.g., Fagus sylvatica, Cochard et al., 2001).

\section{CLIMATE CHANGE AND THE RISK OF FREEZE DAMAGE THE MOST RISKY PERIOD TO ENCOUNTER FREEZE INJURIES}

Growth cessation and the onset of hardening in autumn are triggered by decreasing day length and cold temperature. Most tree species start hardening well before the first occurrence of freezing temperatures (Figure 1). For instance, an absolute minimum temperature of $-14^{\circ} \mathrm{C}$ will occur at the coldest range edge of Fagus sylvatica only once every 100 years (Kollas et al., 2014). However, the $\mathrm{LT}_{50}$ values (median lethal freezing temperature) of Fagus sylvatica are already below $-15^{\circ} \mathrm{C}$ in October for an average year (Tranquillini and Plank, 1989), and we expect them to be even lower in an extremely cold year due to the fast sub-zero acclimation. Similarly, modeling studies confirmed a much higher risk for freeze damage in Picea sitchensis growing in Scotland in spring than in autumn (Cannell et al., 1985). Summarizing, we suggest that the hardening period in autumn does not constitute a critical phase in terms of the risk to encounter freeze injuries. However an unusual early freeze event in autumn may lead to leaf abscission before leaves are fully senescent. Leaf senescence permits a remobilization of leaf nutrients and an early loss of leaves can affect carbon and nutrient storage (Norby et al., 2003) and the initiation and progression of acclimation (Charrier and Ameglio, 2011). Yet, some species take the risk and assimilate till leaves are damaged by freezing temperatures $\left(\mathrm{N}_{2}\right.$-fixing taxa in Alnus, Robinia, and some Salix species; Tateno, 2003). As for autumn, to our knowledge little, if any, winter freezing injuries have been reported in native trees within their natural ranges in response to an abrupt drop of temperatures because the freezing resistance of overwintering tissues is far higher than the absolute minimum temperatures they encounter, except perhaps in Picea rubens Sarg. (DeHayes, 1992).

Among the different overwintering tissues, buds are of high importance because they contain leaf primordia and inflorescences, as well as apical meristems. In spring, after the release of endodormancy, buds enter the ecodormancy phase in which they de-harden stepwise and metabolism resumes. During that stage, buds gradually rehydrate and become more sensitive to freezing temperatures, until they reach a minimum in freezing resistance during leaf emergence (Neuner, 2007). The most sensitive phenological stage occurs during bud burst and leaf emergence, when cells are extremely active. During this stage $\mathrm{LT}_{50}$ values of temperate trees range between -2 and $-8^{\circ} \mathrm{C}$ (Taschler et al., 2004; Neuner, 2007; Lenz et al., 2013) and are highly correlated with the date of flushing in mild and cold climates. Interestingly, new leaves of early flushing species are more freeze resistant than new leaves of late flushing species (Sakai and Larcher, 1987; Lenz et al., 2013; Vitasse et al., 2014a). In contrasts to autumn and winter, several late spring freeze events caused substantial damage to temperate forests in North America (Gu et al., 2008; Augspurger, 2009; Hufkens et al., 2012) and in Europe (Ningre and Colin, 2007; Kreyling et al., 2012a). For instance in 2007, all of Canada and most of the United States underwent a freeze after an abnormally warm period in late March and early April that triggered early leaf-out. Destruction of foliage due to a late spring freeze is a considerable loss for deciduous trees, since it negatively affects the tree's nutrient pool, growth, reproduction, and canopy development. Yet, survival is commonly not affected, except if such events become too frequent. Freeze damage in spring can be partially compensated for by re-foliation, either from activation of dormant buds or development of adventitious buds. However, re-foliation requires additional resources and, most important, leads to a shorter growing season. For instance, after the late spring freeze in North America in 2007, trees recovered their canopy only after 16-34 days, and most of them showed only partial re-foliation. Further investigations need to be conducted to quantify the real impact of foliage destruction by late frost and at which frequency a foliage loss would cause serious damages to the tree. Experimental studies conducted in situ by defoliating parts or the whole canopy of trees to simulate the effect of herbivory may provide insights on the actual cost of foliage loss (e.g., Piper and Fajardo, 2014). It is likely that the loss of foliage due to a late spring freeze would have a larger impact on populations growing near the cold range boundaries, because they experience a very short growing season that restricts the remaining time for recovering or new shoots to mature. Because the end of the growing season is much less flexible than the beginning, given its photoperiod control, there is little leeway to prolong tissue activity. Such massive damages due to late freeze events are quite rare and temperate trees are rarely leafing-out at the "wrong time."

\section{PHENOLOGICAL SHIFTS OF TEMPERATE FORESTS INDUCED BY CLIMATE CHANGE: IS THE RISK OF FREEZE DAMAGE INCREASING?}

Climate warming has led to substantial phenological shifts in temperate trees over the last three decades. Earlier leaf-out and onset of growth has been detected by both, direct observations (e.g., Sparks and Menzel, 2002; Menzel et al., 2006; Fu et al., 2014b) and remote sensing (e.g., Zhou et al., 2001; Zhao and Schwartz, 2003; Zhang et al., 2004; Fu et al., 2014b). However, the phenological response of trees to climate warming is not linear due to interactions with chilling and photoperiod. Thus, the phenological shift is diminished with an increasing level of climatic warming (Körner, 2006), as was recently demonstrated by experimentally warming saplings of Fagus sylvatica and Quercus species (Morin et al., 2010; Fu et al., 2013). Less attention has been paid to the impact of climate change on growth cessation and leaf senescence (Estrella and Menzel, 2006), likely because the autumnal trend of cessation of cambial activity is photoperiodically controlled in 
most temperate tree species (Way, 2011; Takahashi and Koike, 2014). However, in some temperate tree species, such as Sorbus aucuparia or Populus sp., temperature additionally regulates the timing of bud set and growth cessation (Perry, 1971; Heide, 2011; Rohde et al., 2011). Observations and satellite data suggest that climate change is going to extend the canopy duration of temperate trees in Europe, Eurasia, and North America in response to warming (Menzel and Fabian, 1999; Zhou et al., 2001; Delpierre et al., 2009; Vitasse et al., 2009b, 2011; Garonna et al., 2014; Jeong and Medvigy, 2014). While remote sensing is suitable to identify the onset of the growing season by canopy greening, it is hardly possible to identify the end of the active growth period with this method and the timing of leaf colouration has to be interpreted with caution. Leaf colouration might be a rather unsuitable symptom of physiological deactivation that is influenced by frosty nights, long after trees have gone through a cascade of hormonal and structural adjustment, including the formation of the abscission layer. Furthermore, the annual phenological cycle of temperate trees forms an integrated system with a shift in a given phenophase affecting the subsequent phenophase or even the timing of the next years phenophases (Heide, 2003; Fu et al., 2014a).

The occurrence of freezing temperatures in spring is very stochastic. Thus, spring phenology of temperate tree species has to be well adapted to escape freeze damages on longer time scales (Lenz et al., 2013). However, winters are expected to become progressively milder, with an increasing risk of exceptionally warm spells. Because warm spells may induce premature dehardening, the risk of subsequent freezing injuries in late winter and early spring could rise (Pagter and Arora, 2013). Since the mid 1980s, there has been an unresolved debate whether the risk of freeze damages in trees will increase in the next decades under continued climate change, with contrasting results. For instance, Hänninen (1991) predicted an increased risk of freeze damage under expected warmer climate scenario in Finland. Augspurger (2013) drew the same conclusion for 20 woody species in Illinois (USA), while no change or even a reduced risk was found in other studies in the Netherlands and Germany (Kramer, 1994; Scheifinger et al., 2003). These contradicting predictions root in the lack of data for sites where phenological observations were recorded along with air temperature over many years. In sites where such combined datasets are available, late spring freeze events are too rare to conclusively investigate whether the risk of freezing damage has changed over the last decades. Tree species that have low chilling requirements to break dormancy are at greater risk (Pagter and Arora, 2013). More data are needed on the potential of buds to re-acclimate in response to cold temperatures during the ecodormancy phase in spring (Kalberer et al., 2007; Pagter and Williams, 2011).

\section{CONCLUSION AND FUTURE DIRECTIONS IN PHENOLOGY RESEARCH}

This review attempted to give an overview of the ecological significance of low temperature extremes in temperate trees. In general, temperate trees exhibit a sufficiently early onset of hardening in autumn to escape any damage from late season freezing temperatures. Further, trees are far more freeze resistant in winter than the minimum temperatures that have been recorded over centuries, and trees are able to rapidly harden in response to a rapid drop of temperature during this period. However, trees do also rapidly deharden during a warm spell in late winter or early spring. One of the current challenges is to address the extent to which tissues can reharden after a warm spell, and to predict how often these warm spells will occur in the near future.

The greatest risk for temperate trees to encounter freeze damages occurs during the period of leaf-out, though damages are only rarely observed under current climatic conditions. We emphasize that late spring freeze events are climatic extremes with high ecological and evolutionary importance, likely controlling the latitudinal and elevational range limits of temperate tree species (Sakai and Larcher, 1987; Lenz et al., 2013; Kollas et al., 2014). One of the main challenges today is to truly understand the effect of temperature and photoperiod on bud dormancy - from the initiation of endodormancy to budburst - as well as to quantify to what extent freezing resistance of buds varies in relation to temperature fluctuations, especially during the dehardening period, when buds are in ecodormancy. Spring phenology is the key to any risk assessment or prediction with regard to damaging low temperature extremes and the species range limits they set.

\section{AUTHOR CONTRIBUTIONS}

Yann Vitasse led the writing with input from the two other authors.

\section{ACKNOWLEDGMENTS}

We are grateful to NOAA's National Climatic Data Center (NCDC) to provide the temperature data used in Figure 1. We thank Tim Sparks for giving us the access to the Marsham phenological record presented in Figure 3 and Heikki Hänninen for the invitation to contribute this research topic. The research leading to these results has been funded by the European Research Council (ERC) advanced grant 233399 to Christian Körner (project TREELIM).

\section{REFERENCES}

Alberto, F., Bouffier, L., Louvet, J. M., Lamy, J. B., Delzon, S., and Kremer, A. (2011). Adaptive responses for seed and leaf phenology in natural populations of sessile oak along an altitudinal gradient. J. Evol. Biol. 24, 1442-1454. doi: 10.1111/j.1420-9101.2011.02277.x

Alberto, F. J., Aitken, S. N., Alía, R., González-Martínez, S. C., Hänninen, H., Kremer, A., et al. (2013). Potential for evolutionary responses to climate change-evidence from tree populations. Glob. Change Biol. 19, 1645-1661. doi: 10.1111/gcb.12181

Arora, R., Rowland, L. J., and Tanino, K. (2003). Induction and release of bud dormancy in woody perennials: a science comes of age. HortScience 38, 911-921. Augspurger, C. K. (2009). Spring 2007 warmth and frost: phenology, damage and refoliation in a temperate deciduous forest. Funct. Ecol. 23, 1031-1039. doi: 10.1111/j.1365-2435.2009.01587.x

Augspurger, C. K. (2013). Reconstructing patterns of temperature, phenology, and frost damage over 124 years: spring damage risk is increasing. Ecology 94, 41-50. doi: 10.1890/12-0200.1

Barnett, P. E., and Farmer, R. E. (1980). Altitudinal variation in juvenile characteristics of southern appalachian black cherry (Prunus Serotina Ehrh). Silvae Genet. 29, 157-160.

Basler, D., and Körner, C. (2012). Photoperiod sensitivity of bud burst in 14 temperate forest tree species. Agric. For. Meteorol. 165, 73-81. doi: 10.1016/j.agrformet.2012.06.001

Basler, D., and Körner, C. (2014). Photoperiod and temperature responses of bud swelling and bud burst in four temperate forest tree species. Tree Physiol. 34, 377-388. doi: 10.1093/treephys/tpu021 
Beaubien, E. G., and Freeland, H. J. (2000). Spring phenology trends in Alberta, Canada: links to ocean temperature. Int. J. Biometeorol. 44, 53-59. doi: $10.1007 / \mathrm{s} 004840000050$

Beck, E. H., Heim, R., and Hansen, J. (2004). Plant resistance to cold stress: mechanisms and environmental signals triggering frost hardening and dehardening. $J$. Biosci. 29, 449-459. doi: 10.1007/bf02712118

Bennie, J., Kubin, E., Wiltshire, A., Huntley, B., and Baxter, R. (2010). Predicting spatial and temporal patterns of bud-burst and spring frost risk in north-west Europe: the implications of local adaptation to climate. Glob. Change Biol. 16, 1503-1514. doi: 10.1111/j.1365-2486.2009.02095.x

Bresson, C. C., Vitasse, Y., Kremer, A., and Delzon, S. (2011). To what exten is altitudinal variation of functional traits driven by genetic adaptation in European oak and beech? Tree Physiol. 31, 1164-1174. doi: 10.1093/treephys/ tpr084

Burger, H. (1926). Untersuchungen über das Höhenwachstum verschiedener Holzarten. Zürich: Schweizerische Centralanstalt für das forstliche Versuchswesen.

Caffarra, A., and Donnelly, A. (2011). The ecological significance of phenology in four different tree species: effects of light and temperature on bud burst. Int. J. Biometeorol. 55, 711-721. doi: 10.1007/s00484-010-0386-1

Cannell, M. G. R. (1997). Spring phenology of trees and frost avoidance. Weather 52, 46-52. doi: 10.1002/j.1477-8696.1997.tb06268.x

Cannell, M. G. R., Sheppard, L. J., Smith, R. I., and Murray, M. B. (1985). Autumn frost damage on young picea sitchensis 2. Shoot frost hardening, and the probability of frost damage in Scotland. Forestry 58, 145-166. doi: $10.1093 /$ forestry/58.2.145

Cannell, M. G. R., and Smith, R. I. (1986). Climatic warming, spring budburst and frost damage on trees. J. Appl. Ecol. 23, 177-191. doi: 10.2307/2403090

Charrier, G., and Ameglio, T. (2011). The timing of leaf fall affects cold acclimation by interactions with air temperature through water and carbohydrate contents. Environ. Exp. Bot. 72, 351-357. doi: 10.1016/j.envexpbot.2010.12.019

Chen, X. Q., Hu, B., and Yu, R. (2005). Spatial and temporal variation of phenological growing season and climate change impacts in temperate eastern China. Glob. Change Biol. 11, 1118-1130. doi: 10.1111/J.1365-2486.2005.00974.X

Chmielewski, F. M., and Rötzer, T. (2002). Annual and spatial variability of the beginning of growing season in Europe in relation to air temperature changes. Clim. Res. 19, 257-264. doi: 10.3354/Cr019257

Christersson, L. (1978). The influence of photoperiod and temperature on the development of frost hardiness in seedlings of Pinus silvestris and Picea abies. Physiol. Plant. 44, 288-294. doi: 10.1111/j.1399-3054.1978.tb08634.x

Chuine, I. (2010). Why does phenology drive species distribution? Philos. Trans. R. Soc. B Biol. Sci. 365, 3149-3160. doi: 10.1098/rstb.2010.0142

Chuine, I., and Beaubien, E. G. (2001). Phenology is a major determinant of tree species range. Ecol. Lett. 4, 500-510. doi: 10.1046/J.1461-0248.2001.00261.X

Cochard, H., Lemoine, D., Améglio, T., and Granier, A. (2001). Mechanisms of xylem recovery from winter embolism in Fagus sylvatica. Tree Physiol. 21, 27-33. doi: $10.1093 /$ treephys/21.1.27

Cochard, H., and Tyree, M. T. (1990). Xylem dysfunction in Quercus: vessel sizes, tyloses, cavitation and seasonal changes in embolism. Tree Physiol. 6, 393-407. doi: $10.1093 /$ treephys/6.4.393

Coville, F. V. (1920). The Influence of cold in stimulating the growth of plants. Proc. Natl. Acad. Sci. U.S.A. 6, 434-435. doi: 10.1073/pnas.6.7.434

Dantec, C. F., Vitasse, Y., Bonhomme, M., Louvet, J. M., Kremer, A., and Delzon S. (2014). Chilling and heat requirements for leaf unfolding in European beech and sessile oak populations at the southern limit of their distribution range. Int. J. Biometeorol. 1-12. doi: 10.1007/s00484-014-0787-7 [Epub ahead of print]

DeHayes, D. (1992). "Winter injury and developmental cold tolerance of red spruce," in Ecology and Decline of Red Spruce in the Eastern United States, eds C. Eagar and M. Adams (New York: Springer), 295-337. doi: 10.1007/978-1-46122906-3 8

Delpierre, N., Dufrene, E., Soudani, K., Ulrich, E., Cecchini, S., Boe, J., et al. (2009). Modelling interannual and spatial variability of leaf senescence for three deciduous tree species in France. Agric. For. Meteorol. 149, 938-948. doi: 10.1016/j.agrformet.2008.11.014

Engler, A. (1913). Einfluss der Provenienz des Samens auf die Eigenschaften der forstlichen Holzgewächse. Zweite Mitteilung. 10, 190-386.

Estrella, N., and Menzel, A. (2006). Responses of leaf colouring in four deciduous tree species to climate and weather in Germany. Clim. Res. 32, 253-267. doi: $10.3354 / \mathrm{Cr} 032253$
Flint, H. L. (1972). Cold hardiness of twigs of Quercus rubra L. as a function of geographic origin. Ecology 53, 1163-1170. doi: 10.2307/1935430

Francis, J. A., Chan, W. H., Leathers, D. J., Miller, J. R., and Veron, D. E. (2009). Winter northern hemisphere weather patterns remember summer Arctic sea-ice extent. Geophys. Res. Lett. 36, L07503. doi: 10.1029/2009gl037274

Fu, Y. H., Campioli, M., Deckmyn, G., and Janssens, I. A. (2013). Sensitivity of leaf unfolding to experimental warming in three temperate tree species. Agric. For. Meteorol. 181, 125-132. doi: 10.1016/J.Agrformet.2013.07.016

Fu, Y. H., Campioli, M., Vitasse, Y., De Boeck, H. J., Van Den Berge, J., Abdelgawad, H., et al. (2014a). Variation in leaf flushing date influences autumnal senescence and next year's flushing date in two temperate tree species. PNAS 111, 7355-7360. doi: 10.1073/pnas.1321727111

Fu, Y. H., Piao, S., Op de Beeck, M., Cong, N., Zhao, H., Zhang, Y., et al. (2014b). Recent spring phenology shifts in western Central Europe based on multiscale observations. Glob. Ecol. Environ. (in press). doi: 10.1111/geb.12210

Garonna, I., De Jong, R., De Wit, A. J. W., Mücher, C. A., Schmid, B., and Schaepman, M. (2014). Strong contribution of autumn phenology to changes in satellite-derived growing season length estimates across Europe (1982-2011). Glob. Change Biol. (in press). doi: 10.1111/gcb.12625

Gerber, S., Chadæuf, J., Gugerli, F., Lascoux, M., Buiteveld, J., Cottrell, J., et al. (2014). High rates of gene flow by pollen and seed in oak populations across Europe. PLoS ONE 9:e85130. doi: 10.1371/journal.pone.0085130

Gu, L., Hanson, P. J., Mac Post, W., Kaiser, D. P., Yang, B., Nemani, R., et al. (2008). The 2007 eastern US spring freezes: increased cold damage in a warming world? Bioscience 58, 253-262. doi: 10.1641/b580311

Hänninen, H. (1991). Does climatic warming increase the risk of frost damage in northern trees? Plant Cell Environ. 14, 449-454. doi: 10.1111/j.13653040.1991.tb01514.x

Hänninen, H., and Tanino, K. (2011). Tree seasonality in a warming climate. Trends Plant Sci. 16, 412-416. doi: 10.1016/j.tplants.2011.05.001

Hasenauer, H., Nemani, R. R., Schadauer, K., and Running, S. W. (1999). Forest growth response to changing climate between 1961 and 1990 in Austria. For. Ecol. Manage. 122, 209-219. doi: 10.1016/s0378-1127(99)00010-9

Heide, O. M. (1993). Daylength and thermal time responses of budburst during dormancy release in some northern deciduous trees. Physiol. Plant. 88, 531-540. doi: 10.1034/J.1399-3054.1993.880401.X

Heide, O. M. (2003). High autumn temperature delays spring bud burst in boreal trees, counterbalancing the effect of climatic warming. Tree Physiol. 23, 931-936. doi: $10.1093 /$ treephys/23.13.931

Heide, O. M. (2011). Temperature rather than photoperiod controls growth cessation and dormancy in Sorbus species. J. Exp. Bot. 62, 5397-5404. doi: 10.1093/jxb/ err213

Herman, E. M., Rotter, K., Premakumar, R., Elwinger, G., Bae, R., Ehler-King, L., et al. (2006). Additional freeze hardiness in wheat acquired by exposure to $-3^{\circ} \mathrm{C}$ is associated with extensive physiological, morphological, and molecular changes. J. Exp. Bot. 57, 3601-3618. doi: 10.1093/jxb/erl111

Howell, G. S., and Weiser, C. J. (1970). Fluctuations in the cold resistance of apple twigs during spring hardening. J. Am. Soc. Hortic. Sci. 95, 190-192. doi: 10.1093/jxb/erl111

Hufkens, K., Friedl, M. A., Keenan, T. F., Sonnentag, O., Bailey, A., O’keefe, J., et al. (2012). Ecological impacts of a widespread frost event following early spring leaf-out. Glob. Change Biol. 18, 2365-2377. doi: 10.1111/J.1365-2486.2012. 02712.X

Jeong, S. J., and Medvigy, D. (2014). Macroscale prediction of autumn leaf coloration throughout the continental United States. Glob. Ecol. Biogeogr. (in press). doi: 10.1111 /geb.12206

Junttila, O., and Kaurin, А. (1990). Environmental control of cold acclimation in Salix pentandra. Scand. J. For. Res. 5, 195-204. doi: 10.1080/028275890093 82605

Kalberer, S. R., Arora, R., Leyva-Estrada, N., and Krebs, S. L. (2007). Cold hardiness of floral buds of deciduous azaleas: dehardening, rehardening, and endodormancy in late winter. J. Am. Soc. Hortic. Sci. 132, 73-79. doi: $10.1080 / 02827589009382605$

Kalberer, S. R., Wisniewski, M., and Arora, R. (2006). Deacclimation and reacclimation of cold-hardy plants: Current understanding and emerging concepts. Plant Sci. 171, 3-16. doi: 10.1016/J.Plantsci.2006.02.013

Kalvāns, A., Bitāne, M., and Kalvāne, G. (2014). Forecasting plant phenology: evaluating the phenological models for Betula pendula and Padus racemosa spring 
phases, Latvia. Int. J. Biometeorol. doi: 10.1007/s00484-014-0833-5 [Epub ahead of print].

Kasuga, J., Fukushi, Y., Kuwabara, C., Wang, D., Nishioka, A., Fujikawa, E., et al. (2010). Analysis of supercooling-facilitating (anti-ice nucleation) activity of flavonol glycosides. Cryobiology 60, 240-243. doi: 10.1016/j.cryobiol. 2009.12.004

Kolářová, E., Nekovář, J., and Adamík, P. (2014). Long-term temporal changes in central European tree phenology $(1946-2010)$ confirm the recent extension of growing seasons. Int. J. Biometeorol. 58, 1739-1748. doi: 10.1007/s00484-0130779-z

Kollas, C., Körner, C., and Randin, C. F. (2014). Spring frost and growing season length co-control the cold range limits of broad-leaved trees. J. Biogeogr. 41, 773-783. doi: 10.1111/Jbi.12238

Körner, C. (2006). "Significance of temperature in plant life," in Plant Growth and Climate Change, eds J. I. Morison and M. D. Morecroft (Oxford: Blackwell Publishing Ltd), 48-69.

Körner, C. (2012). Alpine Treelines. Basel: Springer.

Körner, C., and Basler, D. (2010). Phenology under global warming. Science 327, 1461-1462. doi: 10.1126/science. 1186473

Kramer, K. (1994). A modelling analysis of the effects of climatic warming on the probability of spring frost damage to tree species in the Netherlands and Germany. Plant Cell Environ. 17, 367-377. doi: 10.1111/j.1365-3040.1994.tb00305.x

Kramer, K. (1995). Phenotypic plasticity of the phenology of seven European tree species in relation to climatic warming. Plant Cell Environ. 18, 93-104. doi: 10.1111/j.1365-3040.1995.tb00356.x

Kremer, A., Ronce, O., Robledo-Arnuncio, J. J., Guillaume, F., Bohrer, G., Nathan, R., et al. (2012). Long-distance gene flow and adaptation of forest trees to rapid climate change. Ecol. Lett. 15, 378-392. doi: 10.1111/j.1461-0248.2012. 01746.x

Kreyling, J., Buhk, C., Backhaus, S., Hallinger, M., Huber, G., Huber, L., et al. (2014). Local adaptations to frost in marginal and central populations of the dominant forest tree Fagus sylvatica L. as affected by temperature and extreme drought in common garden experiments. Ecol. Evol. 4, 594-605. doi: 10.1002/ ece3.971

Kreyling, J., Stahlmann, R., and Beierkuhnlein, C. (2012a). Spatial variation in leaf damage of forest trees and the regeneration after the extreme spring frost event in May 2011. Allg. Forst Jagdztg 183, 15-22.

Kreyling, J., Wiesenberg, G. L. B., Thiel, D., Wohlfart, C., Huber, G., Walter, J., et al. (2012b). Cold hardiness of Pinus nigra Arnold as influenced by geographic origin, warming, and extreme summer drought. Environ. Exp. Bot. 78, 99-108. doi: 10.1016/j.envexpbot.2011.12.026

Kuprian, E., Briceño, V. F., Wagner, J., and Neuner, G. (2014). Ice barriers promote supercooling and prevent frost injury in reproductive buds, flowers and fruits of alpine dwarf shrubs throughout the summer. Environ. Exp. Bot. 106, 4-12. doi 10.1016/j.envexpbot.2014.01.011

Kuwabara, C., Wang, D., Endoh, K., Fukushi, Y., Arakawa, K., and Fujikawa, S. (2013). Analysis of supercooling activity of tannin-related polyphenols. Cryobiology 67, 40-49. doi: 10.1016/j.cryobiol.2013.04.008

Lang, G. A., Early, J. D., Martin, G. C., and Darnell, R. L. (1987).Endo-, para-, and ecodormancy: physiological terminology and classification for dormancy research. HortScience 22, 371-377.

Langlet, O. (1971). Two hundred years genecology. Taxon 20, 653-722.

Larcher, W. (2005). Climatic constraints drive the evolution of low temperature resistance in woody plants. J. Agric. Meteorol. 61, 189-202. doi: 10.2307/ 1218596

Larsen, J. B. (1986). Die geographische variation der weißtanne (Abies alba Mill.) wachstumsentwicklung und frostresistenz. Forstwiss. Centralbl. 105, 396-406. doi: $10.1007 /$ bf02741748

Laube, J., Sparks, T. H., Estrella, N., Höfler, J., Ankerst, D. P., and Menzel, A. (2014). Chilling outweighs photoperiod in preventing precocious spring development. Glob. Change Biol. 20, 170-182. doi: 10.1111/gcb.12360

Le, M. Q., Engelsberger, W. R., and Hincha, D. K. (2008). Natural genetic variation in acclimation capacity at sub-zero temperatures after cold acclimation at 4 degrees C in different Arabidopsis thaliana accessions. Cryobiology 57, 104-112. doi: 10.1016/j.cryobiol.2008.06.004

Leinonen, I., Repo, T., and Hänninen, H. (1997). Changing environmental effects on frost hardiness of scots pine during dehardening. Ann. Bot. 79, 133-137. doi: 10.1006/anbo. 1996.0321
Lenz, A., Hoch, G., Vitasse, Y., and Korner, C. (2013). European deciduous trees exhibit similar safety margins against damage by spring freeze events along elevational gradients. New Phytol. 200, 1166-1175. doi: 10.1111/nph. 12452

Lenz, A., Vitasse, Y., Hoch, G., and Körner, C. (2014). Growth and carbon relations of temperate deciduous tree species at their upper elevation range limit. J. Ecol. (in press). doi: 10.1111/1365-2745.12307

Levitt, J. (1972). Responses of Plants to Environmental Stresses. New York, NY: Academic Press. doi: 10.1111/1365-2745.12307

Li, C. Y., Puhakainen, T., Welling, A., Vihera-Aarnio, A., Ernstsen, A., Junttila, O., et al. (2002). Cold acclimation in silver birch (Betula pendula). Development of freezing tolerance in different tissues and climatic ecotypes. Physiol. Plant. 116, 478-488. doi: 10.1034/J.1399-3054.2002.1160406.X

Li, C. Y., Vihera-Aarnio, A., Puhakainen, T., Junttila, O., Heino, P., and Palva, E. T. (2003). Ecotype-dependent control of growth, dormancy and freezing tolerance under seasonal changes in Betula pendula Roth. Trees-Struct. Funct. 17, 127-132. doi: 10.1007/S00468-002-0214-2

Loehle, C. (1998). Height growth rate tradeoffs determine northern and southern range limits for trees. J. Biogeogr. 25, 735-742. doi: 10.1046/j.13652699.1998.2540735.x

Ma, T., and Zhou, C. (2012). Climate-associated changes in spring plant phenology in China. Int. J. Biometeorol. 56, 269-275. doi: 10.1007/s00484-0110428-3

Mayr, S., and Sperry, J. S. (2010). Freeze-thaw-induced embolism in Pinus contorta: centrifuge experiments validate the 'thaw-expansion hypothesi' but conflict with ultrasonic emission data. New Phytol. 185, 1016-1024. doi: 10.2307/ 27797503

Menzel, A. (2000). Trends in phenological phases in Europe between 1951 and 1996. Int. J. Biometeorol. 44, 76-81. doi: 10.1007/S004840000054

Menzel, A., and Fabian, P. (1999). Growing season extended in Europe. Nature 397, 659. doi: $10.1038 / 17709$

Menzel, A., Sparks, T. H., Estrella, N., Koch, E., Aasa, A., Ahas, R., et al. (2006). European phenological response to climate change matches the warming pattern. Glob. Change Biol. 12, 1969-1976. doi: 10.1111/J.1365-2486.2006. 01193.X

Morin, X., Roy, J., Sonie, L., and Chuine, I. (2010). Changes in leaf phenology of three European oak species in response to experimental climate change. New Phytol. 186, 900-910. doi: 10.1111/j.1469-8137.2010.03252.x

Myneni, R. B., Keeling, C. D., Tucker, C. J., Asrar, G., and Nemani, R. R. (1997). Increased plant growth in the northern high latitudes from 1981 to 1991. Nature 386, 698-702. doi: 10.1038/386698a0

Neuner, G. (2007). "Frost resistance at the upper timberline," in Trees at Their Upper Limit, eds G. Wieser and M. Tausz (Amsterdam: Springer), 171-180. doi: $10.1038 / 386698 \mathrm{a} 0$

Neuner, G., Ambach, D., and Buchner, O. (1999). Readiness to frost harden during the dehardening period measured in situ in leaves of Rhododendron ferrugineum L. at the alpine timberline. Flora 194, 289-296. doi: 10.1007/1-40205074-7_10

Ningre, F., and Colin, F. (2007). Frost damage on the terminal shoot as a risk factor of fork incidence on common beech (Fagus sylvatica L.). Ann. For. Sci. 64, 79-86. doi: 10.1051/Forest:2006091

Norby, R. J., Hartz-Rubin, J. S., and Verbrugge, M. J. (2003). Phenological responses in maple to experimental atmospheric warming and $\mathrm{CO} 2$ enrichment. Glob. Change Biol. 9, 1792-1801. doi: 10.1046/J.1529-8817.2003.00714.X

Ogren, E. (2001). Effects of climatic warming on cold hardiness of some northern woody plants assessed from simulation experiments. Physiol. Plant. 112, 71-77. doi: 10.1034/J.1399-3054.2001.1120110.X

Oleksyn, J., Modrzynski, J., Tjoelker, M. G., Zytkowiak, R., Reich, P. B., and Karolewski, P. (1998). Growth and physiology of Picea abies populations from elevational transects: common garden evidence for altitudinal ecotypes and cold adaptation. Funct. Ecol. 12, 573-590. doi: 10.1046/J.1365-2435.1998. 00236.X

Pagter, M., and Arora, R. (2013). Winter survival and deacclimation of perennials under warming climate: physiological perspectives. Physiol. Plant. 147, 75-87. doi: 10.1111/j.1399-3054.2012.01650.x

Pagter, M., and Williams, M. (2011). Frost dehardening and rehardening of hydrangea macrophylla stems and buds. HortScience 46, 1121-1126. doi: 10.1111/j.1399-3054.2012.01650.x 
Pearce, R. S. (2001). Plant freezing and damage. Ann. Bot. 87, 417-424. doi: 10.1006/anbo.2000.1352

Perry, T. O. (1971). Dormancy of trees in winter. Science 171, 29-39. doi: 10.1126/science.171.3966.29

Piper, F. I., and Fajardo, A. (2014). Foliar habit, tolerance to defoliation and their link to carbon and nitrogen storage. J. Ecol. 102, 1101-1111. doi: 10.1111/13652745.12284

Pisek, A., and Schiessl, R. (1947). Die Temperaturbeeinflußbarkeit der Frosthärte von Nadelhölzern und Zwergsträuchern an der alpinen Waldgrenze. Ber. Nat. Med. Vereins Innsbruck 47, 33-52. doi: 10.1111/1365-2745.12284

Polgar, C., Gallinat, A., and Primack, R. B. (2014). Drivers of leaf-out phenology and their implications for species invasions: insights from Thoreau's Concord. New Phytol. 202, 106-115. doi: 10.1111/nph.12647

Polgar, C. A., and Primack, R. B. (2011). Leaf-out phenology of temperate woody plants: from trees to ecosystems. New Phytol. 191, 926-941. doi: 10.1111/j.14698137.2011.03803.x

Premoli, A. C., Raffaele, E., and Mathiasen, P. (2007). Morphological and phenological differences in Nothofagus pumilio from contrasting elevations: evidence from a common garden. Austral Ecol. 32, 515-523. doi: 10.1111/j.14429993.2007.01720.x

Preston, J. C., and Sandve, S. R. (2013). Adaptation to seasonality and the winter freeze. Front. Plant Sci. 4:167. doi: 10.3389/fpls.2013.00167

Rehfeldt, G. E. (1994). Adaptation of picea-engelmannii populations to the heterogeneous environments of the intermountain west. Can. J. Bot. 72, 1197-1208 doi: 10.1139/b94-146

Richardson, A. D., Keenan, T. F., Migliavacca, M., Ryu, Y., Sonnentag, O., and Toomey, M. (2013). Climate change, phenology, and phenological control of vegetation feedbacks to the climate system. Agric. For. Meteorol. 169, 156-173. doi: 10.1016/J.Agrformet.2012.09.012

Rohde, A., Bastien, C., and Boerjan, W. (2011). Temperature signals contribute to the timing of photoperiodic growth cessation and bud set in poplar. Tree Physiol. 31, 472-482. doi: 10.1093/treephys/tpr038

Rweyongeza, D. M., Yang, R. C., Dhir, N. K., Barnhardt, L. K., and Hansen, C. (2007). Genetic variation and climatic impacts on survival and growth of white spruce in Alberta, Canada. Silvae Genet. 56, 117-127. doi: 10.1016/j.agrformet.2012.09.012

Saenz-Romero, C., Guzman-Reyna, R. R., and Rehfeldt, G. E. (2006). Altitudinal genetic variation among Pinus oocarpa populations in Michoacan, Mexico implications for seed zoning, conservation, tree breeding and global warming. For. Ecol. Manage. 229, 340-350. doi: 10.1016/J.Foreco.2006.04.014

Sakai, A. (1960). Survival of the twig of woody plants at $-196^{\circ} \mathrm{C}$. Nature 185,393 394. doi: 10.1038/185393a0

Sakai, A. (1966). Studies of frost hardiness in woody plants. II. Effect of Temperature on Hardening. Plant Physiol. 41, 353-359. doi: 10.2307/4260654

Sakai, A. (1982). Freezing tolerance of shoot and flower primordia of coniferous buds by extraorgan freezing. Plant Cell Physiol. 23, 1219-1227. doi: $10.1038 / 185393 \mathrm{a} 0$

Sakai, A., and Larcher, W. (1987). Frost Survival of Plants: Responses and Adaptation to Freezing Stress. Berlin: Springer, 62, 321.

Sarvas, R. (1972). Investigations on the annual cycle of development of forest trees. Active period. Commun. Inst. For. Fen. 76, 110.

Savage, J. A., and Cavender-Bares, J. (2013). Phenological cues drive an apparent trade-off between freezing tolerance and growth in the family Salicaceae. Ecology 94, 1708-1717. doi: 10.1890/12-1779.1

Scheifinger, H., Menzel, A., Koch, E., and Peter, C. (2003). Trends of spring time frost events and phenological dates in Central Europe. Theor. Appl. Climatol. 74 41-51. doi: 10.1007/S00704-002-0704-6

Schwartz, M. D., and Reiter, B. E. (2000). Changes in North American spring. Int. J. Clim. 20, 929-932. doi: 10.1002/1097-0088(20000630)20:8<929::AidJoc557>3.0.Co;2-5

Screen, J. A., and Simmonds, I. (2010). The central role of diminishing sea ice in recent Arctic temperature amplification. Nature 464, 1334-1337. doi: 10.1038/nature09051

Screen, J. A., and Simmonds, I. (2013). Exploring links between Arctic amplification and mid-latitude weather. Geophys. Res. Lett. 40, 959-964. doi: 10.1002/grl.50174

Semenov, V. A. (2012). Meteorology Arctic warming favours extremes. Nat. Clim. Chang. 2, 315-316. doi: 10.1038/nclimate1502

Smithberg, M. H., and Weiser, C. J. (1968). Patterns of variation among climatic races of red-osier dogwood. Ecology 49, 495-505. doi: 10.2307/1934116
Sparks, T. H., and Carey, P. D. (1995). The responses of species to climate over 2 centuries - an analysis of the Marsham phenological record, 1736-1947. J. Ecol. 83, 321-329. doi: 10.2307/2261570

Sparks, T. H., and Menzel, A. (2002). Observed changes in seasons: an overview. Int. J. Climatol. 22, 1715-1725. doi: 10.1002/Joc.821

Sperry, J. S., and Sullivan, J. E. M. (1992). Xylem embolism in response to freezethaw cycles and water stress in ring-porous, diffuse-porous, and conifer species. Plant Physiol. 100, 605-613. doi: 10.1104/pp.100.2.605

Steponkus, P. L. (1984). Role of the plasma membrane in freezing injury and cold acclimation. Annu. Rev. Plant Physiol. 35, 543-584. doi: 10.1146/annurev.pp.35.060184.002551

Stushnoff, C., and Junttila, O. (1986). Seasonal development of cold stress resistance in several plant-species at a coastal and a continental location in North Norway. Polar Biol. 5, 129-133. doi: 10.1007/Bf00441691

Takahashi, K., and Koike, S. (2014). Altitudinal differences in bud burst and onset and cessation of cambial activity of four subalpine tree species. Landsc. Ecol. Eng. 10, 349-354. doi: 10.1007/s11355-014-0250-2

Taschler, D., Beikircher, B., and Neuner, G. (2004). Frost resistance and ice nucleation in leaves of five woody timberline species measured in situ during shoot expansion. Tree Physiol. 24, 331-337. doi: 10.1093/treephys/24.3.331

Tateno, M. (2003). Benefit to N2-fixing alder of extending growth period at the cost of leaf nitrogen loss without resorption. Oecologia 137, 338-343. doi: 10.1007/s00442-003-1357-6

Taulavuori, K. M. J., Taulavuori, E. B., Skre, O., Nilsen, J., Igeland, B., and Laine, K. M. (2004). Dehardening of mountain birch (Betula pubescens ssp. czerepanovii) ecotypes at elevated winter temperatures. New Phytol. 162, 427-436. doi: 10.1111/j.1469-8137.2004.01042.x

Till, O. (1956). "Über die frosthärte von pflanzen sommergrüner laubwälder," in: Flora oder Allgemeine botanische Zeitung. Band 143, eds F. Firbas, K. Mothes, and A. Pirson (Jena: Gustav Fisher verlag), 449-542.

Tranquillini, W., and Plank, A. (1989). Ökophysiologische untersuchungen an rotbuchen (Fagus sylvatica L.) in verschiedenen Höhenlagen Nord- und Südtirols. Cent. Gesamte Forstwes. 3, 225-246. doi: 10.1111/j.1469-8137.2004.01042.x

Vitasse, Y. (2013). Ontogenic changes rather than difference in temperature cause understory trees to leaf out earlier. New Phytol. 198, 149-155. doi: $10.1111 / \mathrm{Nph} .12130$

Vitasse, Y., and Basler, D. (2013). What role for photoperiod in the bud burst phenology of European beech. Eur. J. For. Res. 32, 1-8. doi: 10.1007/s10342-0120661-2

Vitasse, Y., Bresson, C. C., Kremer, A., Michalet, R., and Delzon, S. (2010). Quantifying phenological plasticity to temperature in two temperate tree species. Funct. Ecol. 24, 1211-1218. doi: 10.1111/j.1365-2435.2010.01748.x

Vitasse, Y., Delzon, S., Bresson, C. C., Michalet, R., and Kremer, A. (2009a). Altitudinal differentiation in growth and phenology among populations of temperate-zone tree species growing in a common garden. Can. J. For. Res. 39, 1259-1269. doi: 10.1139/X09-054

Vitasse, Y., Porte, A. J., Kremer, A., Michalet, R., and Delzon, S. (2009b). Responses of canopy duration to temperature changes in four temperate tree species: relative contributions of spring and autumn leaf phenology. Oecologia 161, 187-198. doi: 10.1007/s00442-009-1363-4

Vitasse, Y., Francois, C., Delpierre, N., Dufrene, E., Kremer, A., Chuine, I., etal. (2011). Assessing the effects of climate change on the phenology of European temperate trees. Agric. For. Meteorol. 151, 969-980. doi: 10.1016/j.agrformet.2011.03.003

Vitasse, Y., Hoch, G., Randin, C. F., Lenz, A., Kollas, C., Scheepens, J. F., et al. (2013). Elevational adaptation and plasticity in seedling phenology of temperate deciduous tree species. Oecologia 171, 663-678. doi: 10.1007/s00442-012-2580-9

Vitasse, Y., Lenz, A., Hoch, G., and Körner, C. (2014a). Earlier leaf-out rather than difference in freezing resistance puts juvenile trees at greater risk of freeze damage than adult trees. J. Ecol. 102, 981-988. doi: 10.1111/1365-2745.12251

Vitasse, Y., Lenz, A., Kollas, C., Randin, C. F., Hoch, G., and Körner, C. (2014b). Genetic vs. non-genetic responses of leaf morphology and growth to elevation in temperate tree species. Funct. Ecol. 28, 243-252. doi: 10.1111/1365-2435.12161

Viveros-Viveros, H., Saenz-Romero, C., Vargas-Hernandez, J. J., Lopez-Upton, J., Ramirez-Valverde, G., and Santacruz-Varela, A. (2009). Altitudinal genetic variation in Pinus hartwegii Lindl. I: height growth, shoot phenology, and frost damage in seedlings. For. Ecol. Manage. 257, 836-842. doi: 10.1016/j.foreco.2008. 10.021 
Wang, T., Ottlé, C., Peng, S., Janssens, I. A., Lin, X., Poulter, B., et al. (2014). The influence of local spring temperature variance on temperature sensitivity of spring phenology. Glob. Change Biol. 20, 1473-1480. doi: 10.1111/gcb.12509

Way, D. A. (2011). Tree phenology responses to warming: spring forward, fall back? Tree Physiol. 31, 469-471. doi: 10.1093/treephys/tpr044

Way, D. A., and Montgomery, R. A. (2014). Photoperiod constraints on tree performance and migration in a warming world. Plant Cell Environ. doi: 10.1111/gcb.12509 [Epub ahead of print].

Weiser, C. J. (1970). Cold resistance and injury in woody plants: knowledge of hardy plant adaptations to freezing stress may help us to reduce winter damage. Science 169, 1269-1278. doi: 10.1126/science.169.3952.1269

Welling, A., Moritz, T., Palva, E. T., and Junttila, O. (2002). Independent activation of cold acclimation by low emperature and short photoperiod in hybrid aspen. Plant Physiol. 129, 1633-1641. doi: 10.1104/pp.003814

Wisniewski, M., and Fuller, M. (1999). "Ice nucleation and deep supercooling in plants: new insights using infrared thermography," in Cold-Adapted Organisms, eds R. Margesin and F. Schinner (Berlin: Springer), 105-118. doi: 10.1126/science.169.3952.1269

Wisniewski, M., Gusta, L., and Neuner, G. (2014). Adaptive mechanisms of freeze avoidance in plants: a brief update. Environ. Exp. Bot. 99, 133-140. doi: 10.1016/j.envexpbot.2013.11.011

Zhang, X. Y., Friedl, M. A., Schaaf, C. B., and Strahler, A. H. (2004). Climate controls on vegetation phenological patterns in northern mid- and high latitudes inferred from MODIS data. Glob. Change Biol. 10, 1133-1145. doi: 10.1111/J.1529-8817.2003.00784.X
Zhao, T. T., and Schwartz, M. D. (2003). Examining the onset of spring in Wisconsin. Clim. Res. 24, 59-70. doi: 10.3354/Cr024059

Zhou, L. M., Tucker, C. J., Kaufmann, R. K., Slayback, D., Shabanov, N. V., and Myneni, R. B. (2001). Variations in northern vegetation activity inferred from satellite data of vegetation index during 1981 to 1999. J. Geophys. Res. Atmos. 106, 20069-20083. doi: 10.1029/2000jd000115

Conflict of Interest Statement: The authors declare that the research was conducted in the absence of any commercial or financial relationships that could be construed as a potential conflict of interest.

Received: 10 July 2014; accepted: 23 September 2014; published online: 10 October 2014.

Citation: Vitasse Y, Lenz A and Körner C (2014) The interaction between freezing tolerance and phenology in temperate deciduous trees. Front. Plant Sci. 5:541. doi: 10.3389/fpls.2014.00541

This article was submitted to Functional Plant Ecology, a section of the journal Frontiers in Plant Science.

Copyright (c) 2014 Vitasse, Lenz and Körner. This is an open-access article distributed under the terms of the Creative Commons Attribution License (CC BY). The use, distribution or reproduction in other forums is permitted, provided the original author(s) or licensor are credited and that the original publication in this journal is cited, in accordance with accepted academic practice. No use, distribution or reproduction is permitted which does not comply with these terms. 